\title{
PENGENALAN KEPEMIMPINAN DALAM KEWIRAUSAHAAN PADA ORGANISASI KARANG TARUNA DI DESA SUKAMANIS KECAMATAN KADUDAMPIT KABUPATEN SUKABUMI
}

\author{
Surya Perdana ${ }^{1}$, Arif Rahman ${ }^{2}$ \\ 1,2 Program Studi Teknik Industri, Universitas Indraprasta PGRI \\ suryaperdana.st.mm@gmail.com ${ }^{1}$, arif.rahman0876@gmail.com² ${ }^{2}$
}

\begin{abstract}
ABSTRAK
Kegiatan ini bertujuan untuk memberikan pelatihan kepemimpinan dan pelatihan mengenai pemberdayaan masyarakat melalui pengembangan usaha ekonomi produktif kepada pemuda Karang Taruna Desa Sukamanis, Kecamatan Kadudampit, Kabupaten Sukabumi. Metode yang digunakan dalam pengabdian masyarakat ini adalah pertama dengan observasi langsung yaitu: pengabdi langsung datang ke lokasi pengabdiaan untuk memperoleh data. Hal ini kami lakukan pada saat menjelang maupun saat kegiatan berlangsung. Observasi berguna untuk mengetahui kondisi dan kebutuhan yang diperlukan oleh Karang Taruna terutama untuk peningkatan sikap leadership dan juga kewirausahaan bagi para anggota Karang Taruna. Observasi sangat penting untuk mewujudkan kesuksesan kegiatan pengabdiaan masyarakat itu sendiri. Metode kedua adalah melakukan pelatihan mengenai kepemimpinan dan juga kewirausahaan, memberikan cara-cara untuk membentuk sikap kepemimpinan yang baik, memberikan tips untuk menjadi seoarang wirausahaan yang sukses. Hasil dari kegiatan pelatihan kepemimpinan dalam kewirausahaan ini sangat bermanfaat karena dapat menambah wawasan dan pengetahuan para pemuda Karang Taruna, ditambah dengan dukungan dari Kepala Desa Sukamanis sehingga para pemuda Karang Taruna sangat antusias dalam mengikuti pelatihan kepemimpinan dan kewirausahaan.
\end{abstract}

Kata Kunci: Kepemimpinan; Kewirausahaan; Karang Taruna

\begin{abstract}
This activity aims to provide leadership training and training on community empowerment through the development of productive economic enterprises for youth youth in Sukamanis Village, Kadudampit District, Sukabumi Regency. The method used in community service is first by direct observation, namely: servants directly come to the service location to obtain data. We did this before and during the activity. Observation is useful to find out the conditions and needs needed by youth, especially for improving leadership and entrepreneurial attitudes for members of youth organizations. Observation is very important to realize the success of community service activities themselves. The second method is conducting training on leadership and entrepreneurship, providing ways to shape good leadership attitudes, giving tips for becoming a successful entrepreneur. The results of leadership training activities in entrepreneurship are very useful because they can add insight and knowledge to youth youth organizations, coupled with the support of the Village Head Sukamanis in providing support so that youth youth are very enthusiastic in participating in leadership and entrepreneurship training.
\end{abstract}

Keywords: Leadership, Entrepreneurship, Youth

\section{A. PENDAHULUAN}

Dalam kehidupan bermasyarakat sering didengar istilah Karang Taruna, akan tetapi sebagian orang kurang begitu memahami peran dan fungsi dari Karang Taruna itu sendiri. Selama ini sebagian besar masyarakat hanya mengetahui Karang Taruna sebagai tempat perkumpulan pemuda saja, bahkan sebagian besar kegiatan Karang 
Taruna kurang mendapat perhatian di masyarakat. Sebenarnya Karang Taruna dapat diartikan sebagai organisasi sosial yang merupakan wadah pengembangan generasi muda untuk tumbuh dan berkembang atas dasar kesadaran dan tanggung jawab sosial dari, oleh, dan untuk masyarakat, terutama generasi muda di wilayah desa/kelurahan tempat mereka tinggal.

Pengertian karang merupakan tempat berseminya tanaman untuk dapat tumbuh dengan subur, sedangkan taruna adalah manusia pada masa remaja. Jadi pengertian Karang Taruna berarti suatu wadah bagi generasi muda untuk tumbuh dan berkembang secara sehat menjadi generasi muda yang bermanfaat dalam kehidupan masyarakat. Sejak saat itu frasa Karang Taruna menguat sebagai nomenklatur yang menandai lahirnya organisasi sosial yang mengusung misi kesejahtaraan kaum muda pada umumnya (Rotorasiko, 2011, p.21).

Dari pengertian tersebut dapat disimpulkan bahwa Karang Taruna merupakan wadah organisasi kepemudaan yang memiliki peran untuk membina dan memberdayakan pemuda. Dalam menjalankan organisasi Karang Taruna perlu adanya kesadaran dan rasa tanggung jawab sosial dari, oleh dan untuk masyarakat khususnya generasi muda di wilayah Desa/Kelurahan. Sebagai organisasi sosial, Karang Taruna memiliki tugas untuk melaksanakan program pembinaan dan pengembangan serta pemberdayaan pemuda dalam upaya mengembangkan kegiatan ekonomi produktif dengan pendayagunaan semua potensi yang tersedia dilingkungan sekitar baik berupa sumber daya manusia maupun sumber daya alam yang telah ada.

Organisasi Kepemudaan Karang Taruna didirikan dengan tujuan memberikan pembinaan dan pemberdayaan kepada para pemuda, misalnya dalam bidang keorganisasian, ekonomi, olah raga, keterampilan, advokasi, keagamaan dan kesenian. Tujuan dan fungsi Karang Taruna yang terjabarkan dalam pedoman dasarnya merupakan gambaran ideal yang ingin diwujudkan oleh Karang Taruna sebagai organisasi kaum muda untuk berkader sebagai pemimpin umat dan bangsa (Kemenpora, 2010, p.92-93).

Dari beberapa pengertian di atas, maka dapat disimpulksan bahwa Karang Taruna merupakan organisasi kepemudaan non partisan yang menjadi tempat bernaungnya para pemuda dan pemudi dalam mengembangkan potensi, minat, maupun bakatnya yang bertujuan sebagai wahana pemberdayaan dan pengoptimalan potensi dirinya maupun lingkungan serta karakter pemuda yang luhur secara terarah. 
Dengan adanya Karang Taruna sebagai tempat untuk membina dan mengembangkan potensi yang dimiliki oleh generasi muda diharapkan dapat meminimalisir kegiatankegiatan negatif para generasi muda di lingkungan masyarakat serta dapat mengembangkan ide-ide kreativitas serta karakter yang dimiliki setiap pemuda. Dari hasil observasi yang telah kami laksanakan di Karang Taruna Desa Sukamanis Sukabumi, masih ada yang perlu ditingkatkan salah satunya adalah sikap kepemimpinan dalam mengelola suatu organisasi dan juga kemampuan untuk berwirausaha. Oleh karena itu perlu dilakukan kegiatan pengadian masyarakat dengan judul: "Peningkatan Kepemimpinan Dalam Kewirausahaan Pada Organisasi Karang Taruna Di Desa Sukamanis Kecamatan Kadudampit Kabupaten Sukabumi”.

\section{B. LANDASAN TEORI}

\section{Tujuan Karang Taruna}

Karang Taruna merupakan salah satu organisasi sosial kemasyarakatan yang diakui keberadaannya. Selain itu Karang taruna semakin berperan didalam pertumbuhan dan perkembangan setiap anggota masyarakat yang berkualitas, terampil, cerdas inovatif, berkarakter serta memiliki kesadaran dan tanggung jawab sosial dalam mencegah, menangkal, menanggulangi, dan mengantisipasi berbagai masalah kesejahteraan sosial, khususnya generasi muda.

Dalam UU No 40 tahun 2009 tentang Kepemudaan (2009: 19) disebutkan bahwa organisasi kepemudaan dibentuk oleh pemuda berdasarkan kesamaan asas, agama, ideologi, minat dan bakat, atau kepentingan yang tidak bertentangan dengan ketentuan peraturan perundang-undangan. Selain itu organisasi kepemudaan berfungsi untuk mendukung kepentingan nasional, memberdayakan potensi, serta mengembangkan kepemimpinan, kewirausahaan dan kepeloporan.

Sedangkan menurut Permensos 77/HUK/2010 tentang Pedoman Dasar Karang Taruna (2010:3), Karang Taruna bertujuan untuk mewujudkan :

a. Pertumbuhan dan perkembangan setiap anggota masyarakat yang berkualitas, terampil, cerdas, inovatif, berkarakter serta memiliki kesadaran dan tanggung jawab sosial dalam mencegah, menangkal, menanggulangi dan mengantisipasi berbagai masalah kesejahteraan sosial, khususnya generasi muda.

b. Kualitas kesejahteraan sosial setiap anggota masyarakat terutama generasi muda di desa/kelurahan secara terpadu, terarah, menyeluruh serta berkelanjutan. 
c. Pengembangan usaha menuju kemandirian setiap anggota masyarakat terutama generasi muda.

d. Pengembangan kemitraan yang menjamin peningkatan kemampuan dan potensi generasi muda secara terarah dan berkesinambungan.

\section{Peran Karang Taruna Dalam Pelatihan Pendidikan Kepemimpinan}

Karang Taruna merupakan organisasi kepemudaan yang mempunyai peran untuk mengembangkan potensi pemuda. Pendidikan kepemimpinan merupakan salah satu proses pembelajaran untuk menanamkan nilai dan meningkatkan pengetahuan kepemimpinan. Melalui pelatihan pendidikan kepemimpinan ini, pemuda dilatih untuk menguasai teknik berorganiasasi dan kepemimpinan. Menurut Sikula dalam Putro (2016), mengemukakan bahwa pelatihan adalah suatu proses pendidikan jangka pendek yang menggunakan prosedur sistematis dan terorganisir. Pelatihan dapat dikatakan juga sebagai bentuk pengembangan sumber daya manusia dalam membentuk kepribadian peserta didik.

Pelatihan juga merupakan sebuah proses pendidikan yang di dalamnya terdapat proses mengidentifikasi dan mempelajari kekurangan serta melakukan perbaikan. Adapun dalam UU Nomor 20 Tahun 2003 tentang sistem pendidikan kepemimpinan nasional (2003:2), disebutkan bahwa pendidikan adalah usaha sadar dan terencana untuk mewujudkan suasana belajar dan proses pembelajaran agar peserta didik secara aktif mengembangkan potensi dirinya untuk memiliki kekuatan spiritual keagamaan,pengendalian diri, kepribadian, kecerdasan, ahlak mulia, serta keterampilan yang diperlukan dirinya, masyarakat, bangsa dan negara. Pendidikan pada hakikatnya dilaksanakan sepanjang hayat yang mencakup segala aspek, proses dan siklus kehidupan manusia sejak dalam kandungan, hingga usia lanjut atau sampai keliang lahat (Andi Hasdiansyah dan Yoyon Suryono (2016:2). Pendidikan kepemimpinan diselenggarakan dengan alasan sebagai upaya untuk membekali pemuda atau warga belajar sehingga bisa tampil dengan keyakinan mantap dan kepercayaan diri (Lutfi Wibawa 2011:178). Untuk itu pemuda diharapkan dapat menempatkan diri sebagai pemimpin dan agen perubahan dalam mengawal jalannya pembangunan

\section{Kontribusi Karang Taruna Dalam Pelatihan Pendidikan Kepemimpinan}


Karang Taruna merupakan organisasi sosial yang menjadi wadah pengembangan generasi muda yang berkembang atas dasar kesadaran dan tanggung jawab untuk masyarakat khususnya generasi muda sendiri. Melalui program kerja yang dimiliki, Karang Taruna mempunyai kontribusi untuk membangun dan mengembangkan potensi masyarakat khususnya pemuda. Salah satu kontribusi yang diberikan oleh Karang Taruna adalah dalam bentuk pemberdayaan masyarakat dan pemuda. Kontribusi mempunyai makna keterlibatan atau sumbangsih yang dapat berupa materi maupun tindakan.

Kontribusi yang diberikan Karang Taruna dalam program pelatihan pendidikan kepemimpinan adalah untuk meningkatkan pengetahuan dan menggali potensi menurut kemampuan yang dimiliki oleh pemuda melalui proses pemberdayaan. Kontribusi dapat diberikan dalam berbagai bidang yaitu pemikiran, kepemimpinan, profesionalisme, finansial, dan lainnya (Anne Ahira 2012:11). Dengan kontribusi ini pemuda juga berusaha untuk meningkatkan efisiensi dan efektivitas hidupnya.

\section{METODE PELAKSANAAN}

Metode yang dilakukan dalam kegiatan ini adalah melalui beberapa tahap:

1. Observasi langsung.

Observasi langsung yaitu: pengabdi langsung datang ke lokasi pengabdiaan untuk memperoleh data. Hal ini kami lakukan pada saat menjelang maupun saat kegiatan berlangsung. Observasi berguna untuk mengetahui kondisi dan kebutuhan yang diperlukan oleh Karang Taruna Desa Sukamanis, Kecamatan Kadudampit, Kabupaten Sukabumi terutama untuk peningkatan sikap leadership dan juga kewirausahaan bagi para anggota karang taruna. Observasi sangat penting untuk mewujudkan kesuksesan kegiatan pengabdiaan masyarakat itu sendiri.

\section{Pelatihan}

Tim pengabdi melakukan pelatihan mengenai leadership/kepemimpinan dan juga kewirausahaan, memberikan cara-cara untuk membentuk sikap leadership/kepemimpinan yang baik, memberikan tips untuk menjadi seoarang wirausahaan yang sukses.

\section{HASIL DAN PEMBAHASAN}

\section{Hasil}


Hasil dari Pengabdian Kepada Masyarakat berupa pelatihan "Peningkatan Kepemimpinan Dalam Kewirausahaan Pada Organisasi Karang Taruna Di Desa Sukamanis Kecamatan Kadudampit Kabupaten Sukabumi" adalah sebagai berikut:

a. Para pemuda Karang Taruna sangat antusias dengan materi yang disampaikan oleh tim pengabdian.

b. Para pemuda Karang Taruna mendapatkan wawasan dan pengetahuan mengenai kepemimpinan dalam kewirausahaan.

Kegiatan pelatihan Kepemimpinan dalam Kewirausahaan Pada Organisasi Karang Taruna bermanfaat sekali bagi para pemuda Karang Taruna Desa Sukamanis, Kecamatan Kadudampit, Kabupaten Sukabumi, dengan pelatihan ini dapat menambah wawasan dan pengetahuan dari masing-masing peserta. Kepala Desa Sukamanis dalam memberikan dukungan pada pelatihan ini patut diapresiasi, mulai dari perkenalan, penyampaian materi sampai akhir pelatihan. Sehingga para pemuda Karang Taruna antusias sekali saat mengikuti pelaksaan pelatihan.

Dengan penambahan wawasan/pengetahuan mengenai kepemimpinan dalam kewirausahaan pada organisasi Karang Taruna, sehingga secara keseluruhan proses kegiatan pengabdian dapat terlaksana dengan baik. Dapat disimpulkan bahwa kegiatan ini dapat meningkatkan kemampuan, pengetahuan, wawasan dan motivasi para pemuda Karang Taruna dalam menjalankan organisasi Karang Taruna.

\section{Pembahasan}

Kegiatan pelatihan Pengenalan Kepemimpinan Dalam Kewirausahaan Pada Organisasi Karang Taruna Desa Sukamanis, Kecamatan Kadudampit, Kaupaten Sukabumi untuk memberikan wawasan kepada para pemuda Karang Taruna, yang dilakukan oleh team abdimas dari Universitas Indraprasta PGRI Jakarta. Kegiatan dilaksanakan terhadap para pemuda Karang Taruna di balai desa (tempat pertemuan) warga. Kegiatan ini diawali dengan observasi yang dilakukan oleh tim pengabdian tersebuat di mulai dari bulan Juni 2018 untuk mengumpulkan informasi, menganalisa masalah dan mengidentifikasikan segala yang berkaitan dengan Karang Taruna. Dari hasil observasi yang dilakukan oleh tim pengabdian menyimpulkan bahwa dibutuhkan pelatihan mengenai pengenalan kepemimpinan dalam kewirausahaan. Kemudian tim pengabdi menyiapkan materi yang disesuaikan dengan kebutuhan para pemuda karang taruna Desa Sukamanis, Kecamatan Kadudampit, Kabupaten Sukabumi. Setelah materi 
siap maka dilakukan pelatihan/sosialisasi mengenai kepemimpinan dalam kewirausahaan. Proses pelatihan berlangsung dengan baik karena antusias yang luar biasa dari peserta para pemuda karang taruna, dan juga tidak lepas dari bantuan kepala desa yang sangat mendukung dilaksanakannya pelatihan ini. Dengan kerja sama yang baik antara tim pengabdi, peserta karang taruna, dan dukungan dari kepala desa maka pelatihan berjalan dengan sukses, tim abdimas bisa menjalankan tugasnya memberikan pelatihan, dan bagi para peserta pelatihan mendapatkan penambahan wawasan baru mengenai kepemimpinan dalam kewirausahaan dan hal ini sangat berguna bagi para karang taruna di masa yang akan datang.

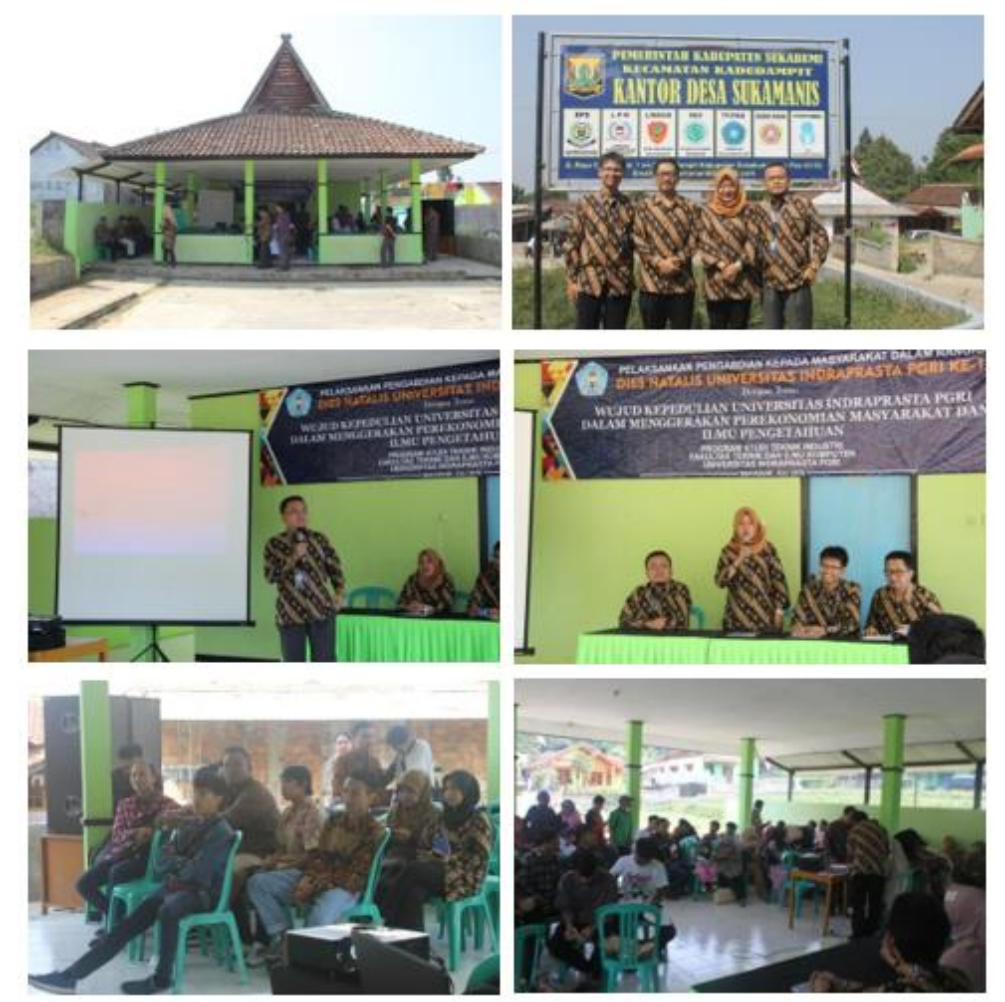

Gambar 1. Sosialisasi Kepada Pemuda Karang Taruna Desa Sukamanis

\section{E. KESIMPULAN}

Berdasarkan hasil pelaksanaan pengabdian pada masyarakat yang telah dilaksanakan di Karang Taruna Desa Sukamanis, Kecamatan Kadudampit, Kabupaten Sukabumi, maka dapat disimpulkan bahwa kegiatan tersebut dapat meningkatkan kemampuan, pengetahuan, wawasan dan motivasi para pemuda Karang Taruna dalam menjalankan organisasi Karang Taruna yang lebih baik sehingga organisasi Karang Taruna bisa bermanfaat buat warga desa Sukamanis. Dalam pelaksanaan kegiatan abdimas ini membutuhkan dukungan semua pihak, termasuk kepala desa, dan juga 
instansi terkait untuk dapat memfasilitasi dan menyediakan pelatihan kepemimpinan dalam kewirausahaan dalam organisasi Karang Taruna.

\section{F. DAFTAR PUSTAKA}

Ahira, A. (2012). "Pengertian Pendidikan." Tersedia: http://anneahira.com/artikelpendidikan/. Diakses tanggal 24 November 2012.

Hasdiansyah A dan Suryono Y (2016). “Evaluasi Program Pelatihan Pemuda Dalam Meningkatkan SDM Di HMI Koordinator Komisariat UNM". Jurnal Pendidikan dan Pemberdayaan Masyarakat Vol.3 No.1 2016, Universitas Negeri Makassar.

Kemenpora. (2009). “Undang-Undang Nomor 40 Tahun 2009 tentang Kepemudaan.” Jakarta: Kemenpora RI.

Putro, R. M. H. H. (2016). “Peran Karang Taruna Dalam Membentuk Sikap Kepemimpinan Pemuda Di Kawasan Desa Wisata Brontokusuman Kecamatan Mergangsan, Kota Yogyakarta." Fakultas Ilmu Pendidikan Universitas Negeri Yogyakarta.

Rotorasiko, T. E. N. (2011). “Jati Diri Karang Taruna Membangun Bangsa.” Yogyakarta: Pustaka Belajar.

Wibawa, L. (2011). "Peranan Pendidikan Nonformal Dalam Pendidikan Dan Latihan Kepemimpinan." Seminar Nasional Jurusan PLS FIP UNY. Hal 171-179. 